Review

\title{
Novel Insights into the Molecular Mechanisms of Ischemia/Reperfusion Injury in Kidney Transplantation
}

\author{
Davide Loizzo ${ }^{1}$, Nicola Antonio di Meo ${ }^{1}$, Mattia Rocco Peluso ${ }^{1}$, Monica Rutigliano ${ }^{1}$, Matteo Matera ${ }^{1}$, \\ Carlos Miacola ${ }^{1}$, Gaetano Palella ${ }^{1}$, Michele Tedeschi ${ }^{1}$, Marco Spilotros ${ }^{1}$, Matteo Ferro ${ }^{2}{ }^{\circ}$, \\ Octavian Sabin Tătaru ${ }^{3}{ }^{(0}$, Mihai Dorin Vartolomei ${ }^{4}{ }^{(D}$, Leonardo Vincenti ${ }^{5}$, Pasquale Ditonno ${ }^{1}$, \\ Michele Battaglia ${ }^{1}$ and Giuseppe Lucarelli ${ }^{1, *}$ (D)
}

Citation: Loizzo, D.; di Meo, N.A.; Peluso, M.R.; Rutigliano, M.; Matera, M.; Miacola, C.; Palella, G.; Tedeschi, M.; Spilotros, M.; Ferro, M.; et al. Novel Insights into the Molecular Mechanisms of Ischemia / Reperfusion Injury in Kidney Transplantation. Transplantology 2021, 2,191-207. https://doi.org/10.3390/ transplantology2020018

Academic Editor:

Wisit Cheungpasitporn

Received: 15 March 2021

Accepted: 24 May 2021

Published: 28 May 2021

Publisher's Note: MDPI stays neutral with regard to jurisdictional claims in published maps and institutional affiliations.

Copyright: (c) 2021 by the authors. Licensee MDPI, Basel, Switzerland. This article is an open access article distributed under the terms and conditions of the Creative Commons Attribution (CC BY) license (https:// creativecommons.org/licenses/by/ $4.0 /)$.
1 Department of Emergency and Organ Transplantation-Urology, Andrology and Kidney Transplantation Unit, University of Bari, 70124 Bari, Italy; d.loizzo27@gmail.com (D.L.); nickant.dimeo@gmail.com (N.A.d.M.); mattia.peluso90@gmail.com (M.R.P.); monica.rutigliano@virgilio.it (M.R.); materamatteo@libero.it (M.M.); cmiacola@hotmail.it (C.M.); gaetano.palella@gmail.com (G.P.); michele_tedeschi@live.it (M.T.); dr.marcospilotros@libero.it (M.S.); pasquale.ditonno@uniba.it (P.D.); michele.battaglia@uniba.it (M.B.)

2 Division of Urology, European Institute of Oncology (IEO)-IRCCS, 20141 Milan, Italy; matteo.ferro@ieo.it

3 The Institution Organizing University Doctoral Studies (I.O.S.U.D.), George Emil Palade University of Medicine, Pharmacy, Sciences and Technology from Târgu Mureș, 540142 Târgu Mureș, Romania; sabin.tataru@gmail.com

4 Department of Cell and Molecular Biology, George Emil Palade University of Medicine, Pharmacy, Sciences and Technology from Târgu Mureș, 540142 Târgu Mureș, Romania; mdvartolomei@yahoo.com

5 Division of General Surgery, Polyclinic Hospital, 70124 Bari, Italy; dr.leonardo.vincenti@gmail.com

* Correspondence: giuseppe.lucarelli@inwind.it

Abstract: Ischemia reperfusion injury (IRI) is one of the most important mechanisms involved in delayed or reduced graft function after kidney transplantation. It is a complex pathophysiological process, followed by a pro-inflammatory response that enhances the immunogenicity of the graft and the risk of acute rejection. Many biologic processes are involved in its development, such as transcriptional reprogramming, the activation of apoptosis and cell death, endothelial dysfunction and the activation of the innate and adaptive immune response. Recent evidence has highlighted the importance of complement activation in IRI cascade, which expresses a pleiotropic action on tubular cells, on vascular cells (pericytes and endothelial cells) and on immune system cells. The effects of IRI in the long term lead to interstitial fibrosis and tubular atrophy, which contribute to chronic graft dysfunction and subsequently graft failure. Furthermore, several metabolic alterations occur upon IRI. Metabolomic analyses of IRI detected a "metabolic profile" of this process, in order to identify novel biomarkers that may potentially be useful for both early diagnosis and monitoring the therapeutic response. The aim of this review is to update the most relevant molecular mechanisms underlying IRI, and also to discuss potential therapeutic targets in future clinical practice.

Keywords: kidney transplantation; ischemia reperfusion injury; complement system; renal damage

\section{Introduction}

According to recent estimates, in 2017 chronic kidney disease (CKD) had a global prevalence of $9.1 \%$ and caused the death of 1.2 million people. Between 1990 and 2017, the global mortality rate from CKD in all age groups increased by $41.5 \%$ (95\% UI 35.2 to 46.5), and in 2017, about 697.5 million (95\% UI 649.2 to 752.0) new cases of all-stage CKD were recorded [1].

Kidney transplantation is the optimal treatment for patients with end-stage renal disease (ESRD): the survival rate is higher than in dialysis and it offers a better quality of life. Worldwide, 81,622 kidney transplants were performed in 2019, 28,306 of which were performed in Europe [2]. Extended criteria donors (ECD) and donors after circulatory 
death (DCD) were accepted by many transplant centers to enlarge the pool of suitable transplant organs and, thus, counteract the shortage of kidney donors [3-8].

Many studies have shown that kidney transplantation using ECDs (donors aged $>60$ years or aged $\geq 50$ years with two of the following-(i) terminal serum creatinine level $>1.5 \mathrm{mg} / \mathrm{dL}$, (ii) cerebrovascular accident as the cause of death and/or (iii) donor history of hypertension-is still associated with a significant reduction in morbidity and increased life expectancy when compared with candidates who remained on dialysis treatment, despite the higher rate of delayed graft function (DGF), primary non function (PNF) and acute rejection with chronic graft failure.

In particular, the incidence of DGF was much higher in grafts from DCD, with the risk of developing DGF being two-fold higher than donors after brain death (DBD) kidneys. This condition was explained by the detrimental effect of the warm ischemia period, which makes DCD organs more vulnerable and more susceptible to suffer the total ischemia time. However, the rate of DGF in this population had no impact on graft survival and graft function. Although 1-year graft function was marginally lower in recipients of DCD kidneys, at 5 years no difference between DCD and DBD kidneys was observed. Similarly, for both the cohorts, the rate of PNF was low, although the incidence was slightly higher for DCD than DBD grafts (3.1\% vs. 2.5\%, $p=0.04$, in updated UK registries).

Patient survival was lower in recipients of DCD donors than in recipients of DBD ( 86.5 vs. $89.4 \%, p<0.0001$ ). Nevertheless, at the time of transplantation, recipients of DCD kidneys were older than DBD (medium age 54 vs. 47 years) and adjusted patient survival showed no significative difference between the two populations of recipients (HR 1.18, $p=0.28$ ). Moreover, a recent US registry analysis showed that DCD that fulfill the criteria for ECD had inferior graft survival compared with kidneys from standard criteria donors, but no difference between DCD and DBD kidneys in the ECD cohort was shown [9-15].

One of the most important mechanisms involved in delayed or reduced graft function is ischemia/reperfusion injury (IRI). This is an unavoidable process, followed by a proinflammatory response that enhances the immunogenicity of the graft and risks of acute rejection [16-18]. Several biologic and immune mechanisms are involved in IRI and in the last decades various studies have highlighted the molecular pathophysiology of this complex process. The aim of this review is to update and highlight the molecular mechanisms underlying IRI, and also to discuss potential therapeutic targets in future clinical practice.

IRI is a complex set of pathophysiologic mechanisms involving many biologic pathways, such as transcriptional reprogramming, the activation of apoptosis and cell death, the activation of the innate and adaptive immune responses, and endothelial dysfunction [18]. Before considering these pathways, it is necessary to explore the single mechanisms involved in each phase.

\section{Ischemia and Reperfusion}

\subsection{Ischemia}

Ischemia is caused by a reduced oxygen supply in tissues, associated with a lack of removal of metabolic end-products due to the imbalance in metabolic supply and demand. This complex condition leads to a severe tissue and intracellular dysfunction. The first response of cells in this condition is to switch the metabolism from aerobic to anaerobic, thus reducing adenosine triphosphate production (ATP) in the cell. Consequently, lactate levels rise in the cell to continue to produce ATP, leading to intracellular acidosis [19]. At this point, a chain of reactions occurs in the cell: $\mathrm{Na}^{+} / \mathrm{K}^{+}$ATPase activity is inhibited; cytoskeletal proteins disrupt, enlarging the cell conformation and contributing to the loss of the specific structural conformation; lysosomal enzymes leak inside the cell. Consequently, $\mathrm{Na}^{+}$concentration levels in the cell rise and are responsible for decreased $\mathrm{Ca}^{2+}$ excretion. Intracellular $\mathrm{Ca}^{2+}$ accumulation activates $\mathrm{Ca}^{2+}$-dependent proteases such as calpains. Nevertheless, calpains are still partially disabled by intracellular acidosis, but this is restored in the reperfusion phase, increasing the activity of calpains [19]. Furthermore, due to $\mathrm{Ca}^{2+}$ 
overload, reactive oxygen species (ROS) are produced in the mitochondria, which after reperfusion, cause the mitochondrial permeability transition pores (mPTP) to open. It is notable that only small amounts of ROS are produced during the ischemia as compared to the whole IRI process. This is due to the reduction of cytochromes, xanthine oxidase and the activation of nicotinamide adenine dinucleotide phosphate (NADPH) oxidase when large amounts of oxygen reach the cell in the reperfusion phase [20-23].

\subsection{Reperfusion}

This phase is characterized by the harmful effect of restoring oxygen levels. Intracellular $\mathrm{pH}$ normalizes but calpains, which have been activated by higher levels of $\mathrm{Ca}^{2+}$, remain activated. Furthermore, normoxemia induces a burst of ROS production, associated with a reduction of scavenger molecules $[18,19]$. ROS can activate several harmful pathways for the cell, such as lipid peroxidation or proteins carbonylation, causing membrane and DNA injury [24]. Mitochondria dysfunction, combined with ROS production and $\mathrm{Ca}^{2+}$ overload, causes the MPTP to open, which allows the mitochondria to release cytochrome $C$, mitochondrial DNA (mtDNA) and succinate. These elements can induce programmed cell death, also known as apoptosis, as well as necrosis. Upon ischemia, organized cell death relies on the intrinsic pathway, taking into account mitochondrial dysfunction and the activation of Caspase 9. Nevertheless, when reperfusion injury occurs, the extrinsic pathway of apoptosis seems to predominate, involving Caspase 8 activation. In this scenario, the spread of tumor necrosis factor $\alpha(\mathrm{TNF} \alpha)$ and other extrinsic mediators of death through the restored blood flow seem to be responsible for the activation of Caspase 8 .

Besides apoptosis, there is another form of cell death which can trigger inflammation. This phenomenon is called necroptosis: it is triggered by the activation of receptorinteracting protein 1 (RIP 1) that interacts with RIP 3 through the homotypic RIP interaction motif to form an auto-phosphorylated complex called the necrosome. The necrosome, in turn, activates other kinases, which leads to necrosis through lysis of the plasma membrane. Recently, it has been demonstrated that molecules released during necrosis and necroptosis act as danger/damage-associated molecular patterns (DAMPs), which can involve and activate the whole immune response $[25,26]$.

\subsection{Endothelial Dysfunction}

Endothelial cells are severely affected by I/R-related damage. Loss of the cytoskeleton, glycocalyx and alterations of cell conformation lead to an increased permeability and to fluid leakage into the interstitium. Endothelial cells start to produce several substances such as platelet-derived growth factor (PDGF) and endothelin-1 (ET1), which induce capillary vasoconstriction. This phenomenon is increased by the lower concentration of nitric oxide (NO) and nitric oxide synthase downregulation, associated to a higher response of endothelial cells to the vasoconstrictive action of thromboxane-A2, prostaglandins and angiotensin-II [27-30].

In the kidney, peritubular capillaries have a limited ability to regenerate following injury. Capillary damage may induce permanent sequelae, associated with the production of transforming growth factor- $\beta$ (TGF- $\beta$ ) and connective tissue growth factor (CTGF), which lead to interstitial fibrosis and tubular atrophy (IFTA) [31]. It has recently been shown that in recipients developing allograft dysfunction and IFTA, a central role is played by endothelial cells and the endothelial-to-mesenchymal transition (EndMT). Different complex pathways control the EndMT, one of which is the complement. Curci and colleagues studied the role of the complement in an animal model: recombinant $\mathrm{C} 1$ inhibitor is able to limit collagen deposition $24 \mathrm{~h}$ after IRI, preserving the endothelial cell density and physiological conformation. Comparing treated with untreated recipients, there was a significant reduction of $\alpha$-smooth muscle actin expression in the former, which means a lower ability to convert the injury into a fibrotic response. Furthermore, the authors showed that C3a and C5a may activate transcription signaling, which induces the EndMT [32]. 
IRI in the kidney, like inflammation, induces endothelial expression of p-selectin. This glycoprotein interacts with p-selectin glycoprotein 1 (PSGL1), expressed on the leukocytes surface, resulting in leukocyte chemotaxis and transmigration of immune cells to the interstitium. The $\beta 2$-integrins and intercellular adhesion molecule 1 (ICAM1) connection allows for the adherence of leukocytes to endothelial cells, while platelet endothelial cell adhesion molecule (PECAM1) interaction permits leukocytes transmigration into the interstitial compartment $[33,34]$.

\section{Immune Response}

Inflammation and the immune response play an important role in IRI, involving the innate and adaptive immune systems as well.

\subsection{Innate Immune Response}

The most ancient part of the immune system, which has remained unchanged through evolution, is the innate immune response. It works in a non-specific manner, activating different cells and mediators against injury or foreign bodies to induce a fast and immediate response.

One of the major actors of the innate immune response is the Toll-like receptors (TLRs). TLRs are transmembrane proteins that act as pattern recognition receptors (PRR); they are expressed on cellular membranes and in the cytosol of immune-related cells, such as leukocytes, monocytes and endothelial cells $[35,36]$.

The human TLR family is composed of 10 different types of TLRs receptors, denominated TLR1 to TLR10. It has been shown that in tubular epithelial cells, TLR4 and TLR2 are upregulated during ischemia [37], playing a relevant role in inducing apoptosis and sterile inflammation [38]. The activation of TLR4 and TLR 2 results in the expression of pro-inflammatory genes and then in the burst of inflammatory response. Genes activated by TLRs include the nuclear factor kappa-light-chain-enhancer of activated B cells (NF-kB), IFN-regulatory factor 3 (IRF3), inhibitor of nuclear factor-kB kinase (IKK) and TANK-binding kinase-1 (TBK1) [18].

It has been shown that during IRI in the kidney an important role is played by TLR4. In a rat allogenic transplant model, there was shown to be a strong correlation between TLR4 expression and graft dysfunction [39]. Moreover, IRI is less frequent in TLR4 knockout mice or in kidneys from donors with TLR4-loss of function, related to a reduced concentration of pro-inflammatory cytokines in the kidney and better outcomes in terms of immediate graft function [40].

The most important pro-inflammatory cytokines, whose release is controlled by TLR4, include IL6, IL1- $\beta$, TNF $\alpha$ and other mediators involved in the chemo-attraction of neutrophils like macrophage inflammatory protein 2 (MIP2) [40]. Other molecules involved in leukocyte "rolling" and migration into the interstitial space, like E-selectin and vascular cell adhesion molecule 1 (VCAM1), are also expressed after TLR4 activation. It has been shown by Chen and colleagues that, in TLR4 knockout mice during IRI, the overexpression of adhesion molecules was absent and not even the addition of HMGB1 to the endothelial cells of those mice was able to induce the expression of the adhesion genes [41].

Finally, TLR4 activation acts on circulating cells of the innate immune response, such as neutrophils and macrophages, to promote the entire immune system activation process. Neutrophils are the first agents to undergo injury and ROS release, which enhance the renal tissue damage [42]. Furthermore, pro-inflammatory cytokines and proteolytic enzymes are released by macrophages, whose activation can increase interstitial concentrations of TNF- $\alpha$, IL- $1 \beta$ and interferon- $\gamma$ (IFN- $\gamma$ ) [43]. It has been demonstrated that the interstitial infiltration of neutrophils and macrophages is reduced in TLR-4 knockout mice subjected to IRI, thus lowering the inflammatory responses associated to the histopathological damage pattern, including tubular necrosis, tubular dilatation, the formation of casts and interstitial fibrosis. All those patterns are suggestive of severe inflammation, which is known to lead to interstitial fibrosis in renal tissue $[30,44]$. 
During IRI, TLR2 is also highly upregulated, leading to a stronger burst of the inflammatory response. As demonstrated by Leemans et al., renal damage during IRI was reduced in knockdown mice for TLR2 as compared to wild-type mice: a lower concentration of IL6, MIP2 and fewer infiltrating leukocytes were demonstrated [45,46] (Figure 1).

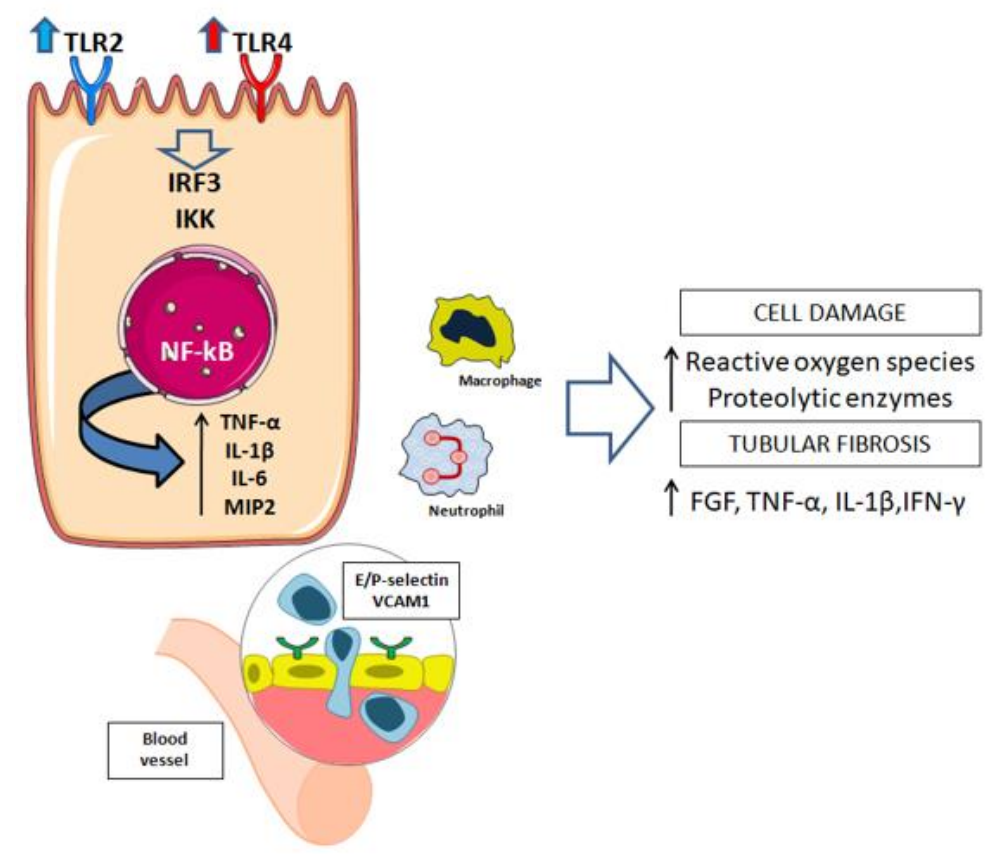

Figure 1. Renal tubular epithelial cell during ischemia.

In this scenario, a humanized immune globulin has recently been tested as a monoclonal antibody against TLR2. This molecule, denominated OPN-305, is intended to prevent reperfusion injury following renal transplantation. A phase I single-center, prospective, randomized, double-blind, placebo-controlled study was performed by Reilly and colleagues to see whether it reduced delayed graft function in recipients of deceased donor kidneys. OPN-305 produced a full TLR2 receptor blockade of CD14(+) and CD45(+) cells (monocytes), with a linear effect on the duration of the inhibition of interleukin- 6 release after TLR2 stimulation. Further studies are needed to test its efficacy in a larger population [47].

\subsection{Innate to Adaptive Immune Response Translation}

Dendritic cells (DCs) are highly specialized bone marrow (BM)-derived antigenprocessing and -presenting cells (APCs) that are crucial to the induction and integration of adaptive immunity; they have several roles and are central players in the pathogenesis of IRI.

DCs are activated by TLRs, which are present on their cellular surface and can perceive DAMPs. DCs are an abundant component of the inflammatory cell infiltrate that appears in response to IRI and are able to activate the adaptive immune system by presenting the antigens to T- and B-cells or releasing cytokines in the interstitial space, thus activating the whole immune cascade [48]. In cases of a donor after brain death (DBD) transplantation, the DCs activation starts already in the donor. Oxidative stress and complement activation in the donor activate DCs, enhancing their function as APCs to the recipient T-cells [49].

DCs' activation contributes to allograft dysfunction in both the earlier and later stages. It has been seen that in the first $24 \mathrm{~h}$ after IRI, DCs release several pro-inflammatory mediators such as TNF $\alpha$, IL6, monocyte chemoattractant protein 1 (MCP1) and chemokine ligand 5 (CCL5) [50]. Nevertheless, it has recently been shown in kidney transplant biopsies performed 15 days after transplantation that a higher density of DCs is associated with poor graft survival and poor patient outcome. From a histologic point of view, a higher density of DCs is also associated with inflammation, tubular atrophy and increased 
T-cell proliferation. One of the main effectors of the interaction between DCs and Tcells is sphingosine 1-phosphate (S1P). S1P is a sphingolipid that acts as an important mediator of the immune system cells' crosstalk. It is produced by the phosphorylation of sphingosine by sphingosine-kinases and is the natural ligand for a family of five $G$ protein-coupled receptors (S1P1-5). These receptors evoke several intracellular responses: Bajwa et al. have demonstrated that S1P3-deficient mice are protected during IRI, as they display an immature phenotype of DCs. Furthermore, the authors showed that wild-type DCs activated the Th1/IFN- $\gamma$ pathway, while S1P3-deficient DCs activated the Th2/IL4 pathway. They concluded that the absence of S1P3 on the DCs' surface prevents DC maturation and promotes a "tolerogenic" response. These aspects warrant further study for clinical support purposes, to prevent and treat IRI-related allograft dysfunction [51].

\subsection{Adaptive Immune Response}

The most important feature of the adaptive immune system, once a specific "non self" antigen is recognized, is to set up an antigen-specific response and to create an immunity memory. The main cells involved in the adaptive immune response are B- and T-cells, which also contribute in different ways to the IRI damage and IRI-associated immune reaction.

T-cells are activated when T-cell receptors (TCR) expressed on the lymphocyte surface bind to the major histocompatibility complex (MHC) on the APC. This interaction may occur in two different ways: in a direct manner, when TCR binds to unprocessed allogenic MHC on the donor APC; in an indirect manner, when the recipient APC processes and displays the donor antigens on the surface and exposes them to the T-cells via the MHC [52].

It is known that T helper CD4+ cells (Th) and T-cytotoxic cell CD8 + are important mediators of IRI and have been found in high percentages in renal tissue upon ischemia-reperfusion damage, whereas T-cell-deficient mice show a reduced kidney IRI intensity [53-56]. When activated, T-cells start to produce large amounts of pro-inflammatory cytokines, becoming one of the main effectors of kidney damage.

CD4+ T-cells are subdivided into three sub-phenotypes: Th1, Th2 and Th17. The phenotype expression starts with their maturation in lymphoid tissue, when it is denominated as polarization. Polarized T-cells can release different cytokines, expressing different transcription factors when activated by DCs, macrophages, natural killer cells and basophils. Cytokines released by each T-cell subset can activate the same subset, also enhancing the subset stimulation and the immune response [53,56].

The most important cytokine released by Th1 cells is IFN $\gamma$, which can activate macrophages, leading to an increased production of ROS, NO and lysosomal enzymes. Nevertheless, the most relevant role in IRI is played by Th17 cells. The main effectors of Th17 are IL17 and IL22, which are released after the activation of the signal transducer and activator of transcription 3 (STAT3) transcription factors, and retinoic acid-related orphan receptor $\mathrm{t}(\mathrm{ROR} \gamma \mathrm{t})$, respectively. It has been shown, indeed, that STAT3 deficiency is protective against IRI. STAT3 knockout mice show a downregulation of Th17 activity, and a lower inflammation response during IRI [57]. Loverre et al. showed that the Th1 phenotype is mostly expressed in kidney transplant recipients when DGF occurs; however, in the literature. both Th1 and Th17 cells are associated with T-cell-mediated rejection [58-61].

Furthermore, it has been demonstrated by Ko et al. that the transcriptional activity in T-cells is already enhanced $6 \mathrm{~h}$ after IRI and that these changes in genes transcription persist for up to 4 weeks after the event. In the early phases of transcriptional activity in the study, the genes controlling immune cell tracking and cellular movement were those most closely involved. Later, gene expression shifted to genes related to products involved in cellular and humoral immune responses. Nevertheless, the authors showed that the CC motif chemokine receptor 5 (CCR5) was one of the most highly upregulated genes throughout their observation. Subsequently, the addition of the CCR5 antibody led to a decreased T-cell activation and a decreased IRI entity, confirming the importance of this gene in the IRI pathogenesis [62]. 
T-regulatory cells (Treg) are a subset of CD4+ cells that most likely play a protective role in renal IRI. Tregs can be differentiated from other T-cells by their expression of FoxP3; their function is to permit self-tolerance, as well as to downregulate the innate and the adaptive immune responses. Treg action is mediated by the production of immune-suppressive cytokines such as IL10 and TGF $\beta$, which inhibit several immune cells like neutrophils, macrophages and T-cells, and promote tissue repair by stimulating macrophages and fibroblasts to synthesize collagen and matrix. Tregs could play an interesting role in inducing graft tolerance and potentially reducing IRI. In addition, several clinical trials are currently running to evaluate the efficacy of FoxP3 cellular therapy in kidney transplantation (NCT02091232, NCT03284242, NCT01446484) [63-97]. However, the effect of immune-suppressive agents on the Treg phenotype needs further study, since these drugs may influence the Treg phenotype, inducing a phenotype switch which mimics Th cells and allows FoxP3+ cells to secrete pro-inflammatory cytokines [68-70].

\section{Complement System}

One of the most important factors playing a crucial role in the response to IRI is the complement system. This system includes membrane-bound receptors, regulatory proteins and enzymes that are able to activate three different pathways. The three pathways comprise a classical pathway (C1q pathway), an alternative pathway (C3 pathway) and the lectin pathway.

The lectin pathway (LP) has recently been identified as one of those most strongly involved, playing a pivotal role in the complement activation upon I/R injury [71]. The activation of LP requires a complex interaction between pattern recognition receptors (PPRs) like collectins or ficolins and mannan-binding serin protease (MASP). One of the most frequently studied lectins is collectin-11 (CL11), a soluble PPR that contains a carbohydrate recognition domain and a MASP-binding domain. It has been shown that upon IRI, the production of CL11 by tubular cells is enhanced. Several studies have demonstrated that in a murine IRI model, CL11-deficient mice were protected from post-ischemic complement activation, showing the pivotal role of this protein in promoting inflammation and ischemic stress $[72,73]$.

Once this interaction occurs, the complex MASP collectins can bind to carbohydratebearing ligands expressed on the surface of stressed cells, leading to the activation of MASPs, which cleave C4 and C2 components and subsequently activate the C3 pathway [74].

The C3 pathway starts when $\mathrm{C} 3$ convertase has been activated. $\mathrm{C} 3$ convertase cleaves $\mathrm{C} 3$, producing $\mathrm{C} 3 \mathrm{a}$ and $\mathrm{C} 3 \mathrm{~b}$. The latter, together with $\mathrm{C} 4 \mathrm{~b} 2 \mathrm{~b}$, creates $\mathrm{C} 5$ convertase, which cleaves $\mathrm{C} 5$ into $\mathrm{C} 5 \mathrm{a}$ and $\mathrm{C} 5 \mathrm{~b}$. $\mathrm{C} 5 \mathrm{~b}$ is one of the most important factors in assembling the membrane attack complex (MAC), merging with C6 to C9. The MAC, when inserted into the cellular membrane, can induce cell death and the inflammatory response, activating the NF-kB pathway, while other effectors (C3a, C5a) lead to chemotaxis of macrophages and neutrophils [71,75].

The complement system plays a pivotal role in modulating the immune system and in promoting organ rejection during IRI. As regards this issue, it has been shown that upon IRI, the balance between complement activation and deactivation is shifted to activation. Normally, soluble proteins are able to block $\mathrm{C} 3$ and $\mathrm{C} 5$ convertases, modulating complement effectors, whereas in the IRI condition, the upregulation of the convertases activity may induce an uncontrolled complement activation leading to injury and graft rejection [76]. Furthermore, the complement can act at all levels of immune responses, from APCs to lymphocytes. In fact, complement factor receptors C3aR and C5aR1 are expressed on the surface of APCs. Upon IRI and complement activation, C3a and C5a enhance the APC priming activity on T-cells, increasing the expression of costimulatory receptors and the presentation of antigens [64]. On T-cells, complement factors can also influence their differentiation and proliferation, but it is on B-cells that they can directly promote their response. This is because complement receptor 2 (CR2), which contributes to switching the 
antibody production from IgM to IgG upon alloantigen stimulation via APC binding, is expressed on the B-cells' surface [71].

Moreover, the complement can also act on kidney stromal cells, including vascular cells such as pericytes and endothelial cells. These cells play an important role in renal fibrosis and scar formation after kidney injury, contributing to the development of renal dysfunction after IRI. The role of the complement has recently been investigated in a swine model of IRI, highlighting the importance of the pericyte-to-myofibroblast transdifferentiation (PMT) [77]. One of the effectors of the complement involved in PMT is C1: treatment by a $\mathrm{C} 1$ inhibitor (C1-INH) was shown to significantly preserve the phenotype of pericytes, maintaining the microvascular density and capillary lumen area at the tubulointerstitial level, thereby preventing collagen deposition and scar formation. Moreover, the endothelialto-mesenchymal transition (EndMT) contributes to the development of renal graft fibrosis. In in vitro studies, it was demonstrated that C3a and C5a led to an altered endothelial phenotype, associated with an increased expression of fibroblast markers and decreased expression of specific endothelial markers. In this scenario, the Akt pathway plays a central role for the C3a- and C5a-induced EndMT in vitro. This evidence has been confirmed in a swine model of IRI, which demonstrated that when the complement was inhibited, the EndMT process rarely developed [32,77,78]. In further studies, the role of other factors, which may be modulated by the complement and may have a relevant role in tubular senescence and graft function after IRI, was also investigated. Castellano et al. found the expression of the $\mathrm{C} 5 \mathrm{a}$ receptor $(\mathrm{C} 5 \mathrm{aR})$ in renal tubular epithelial cells. When this receptor is activated, it induces aberrant DNA methylation in epithelial cells, silencing genes involved in cell cycle control, DNA damage control and signaling. These epigenetic modifications lead to a downregulation of the BCL9, CYP1B1 and CDK6 genes, inducing an upregulation of cell-cycle arrest markers such as p53 and p21. These findings have been confirmed in a swine model of IRI, demonstrating that complement activation affects the DNA methylation of genes involved in tubular senescence [79]. Another gene with pleiotropic functions in preventing cell aging is Klotho. The expression of this gene was remarkably reduced in a swine model of IRI, and associated with NF-kB activity and complement activation. Considering the anti-senescence and anti-fibrotic effects of Klotho at renal levels, it has been hypothesized that this acquired deficiency of Klotho subsequent to IRI might contribute to DGF-associated chronic allograft dysfunction and earlier graft failure [80] (Figure 2).

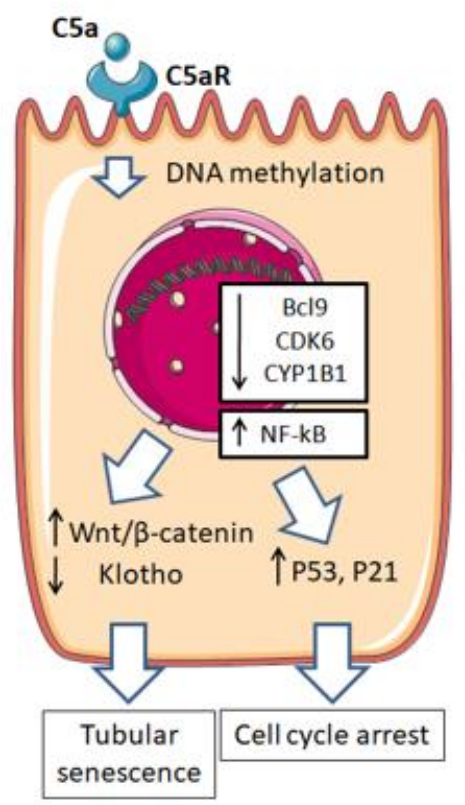

Figure 2. Complement activation induces epigenetic modifications in renal tubular epithelial cells. 


\section{Cellular Metabolism Alterations in Ischemia-Reperfusion Injury}

The recent introduction of high-throughput technologies for the identification and quantification of low-molecular-weight metabolites has led to global metabolic assessments of the cellular state in normal and pathological conditions [81-91]. This approach can be used to define the "metabolic fingerprint" of a disease and identify novel biomarkers that may potentially be useful for both early diagnosis and monitoring the therapeutic response $[92,93]$.

Recently, several studies investigating the multiple effects of I/R on cellular metabolism and transmembrane transport, evaluating the effect on tubular function with metabolomic analysis, have been published (Table 1).

Table 1. Main metabolic alteration described in different kidney transplant models. DGF: delayed graft function; IGF: immediate graft function; (+) increased levels; (-) reduced levels.

\begin{tabular}{|c|c|c|c|}
\hline Phase & Metabolites (+I-) & Model & Reference \\
\hline Ischemia & $\begin{array}{c}\text { Lactate, Choline }(+) \\
\text { Amino acids (valine, alanine, } \\
\text { glutamate, glycine) }(+) \\
\text { Glutathione }(-)\end{array}$ & $\begin{array}{c}\text { Swine kidney } \\
\text { auto-transplantation }\end{array}$ & [94] \\
\hline $\begin{array}{c}\text { Reperfusion } \\
\text { (kidney with DGF) }\end{array}$ & $\begin{array}{c}\text { Glucose }(+) \\
\text { Glutathione }(-)\end{array}$ & $\begin{array}{c}\text { Human cadaveric } \\
\text { perfusate }\end{array}$ & [95] \\
\hline $\begin{array}{c}\text { Reperfusion } \\
\text { (kidney with IGF pool) }\end{array}$ & $\begin{array}{l}\text { 3-hydroxybutyrate }(+) \\
\text { Lactate }(+) \\
\text { Citrate, glutamate }(+)\end{array}$ & $\begin{array}{c}\text { Human cadaveric } \\
\text { perfusate }\end{array}$ & [95] \\
\hline Ischemia & $\begin{array}{c}\text { Glutamate }(+) \text { Serine }(+) \\
\text { Isovalerylglycine }(+) \\
\text { Proline }(+) \text { Aminobutyrate }(+) \\
\text { Choline }(+)\end{array}$ & Swine kidney IRI serum & [96] \\
\hline Reperfusion & $\begin{array}{c}\text { Citrate }(+) \text { Pyruvate }(+) \\
\text { 3-hydroxybutyrate }(+) \\
\text { 3-aminoisobutyrate }(+) \\
\text { Betaine }(+) \text { Carnosine }(+) \\
\text { N-phenylacetylglycine }(+)\end{array}$ & Swine kidney IRI urine & [96] \\
\hline
\end{tabular}

Most research has been conducted on kidney preservation solutions. Preservation strategies often rely on lowering the metabolic activity rate of the organ to counteract the hypoxic condition and subsequent ischemia. Cold storage preservation solutions have been historically used to reduce the metabolic requirements of organs and attenuate ischemic/hypoxic injury and are currently used in the clinical practice. Organ preservation solutions may contain free radical scavengers like reduced glutathione and other substances that are taken up from the medium and utilized by the kidney, in particular glucose and gluconate. Other metabolites, conversely, appear in the medium as a consequence of cellular metabolism subsequent to their release by the graft. Authors have demonstrated that different conditions of preservation have an impact on the tissue metabolism of the kidney in both animal and human models.

In a swine model of auto-transplantation, a metabolomic analysis of kidney perfusate performed with nuclear magnetic resonance imaging (MRI) showed that the metabolite content varied with time, showing an increase of lactate, choline and amino acids (valine, alanine, glutamate, glycine) and a decrease of glutathione after the ischemic period. Furthermore, metabolites were positively (amino acids) or negatively (glutathione) related with serum creatinine 3 months after transplantation [94]. This kind of experiment was also conducted on cadaveric kidneys by Guy et al. The analysis of NMR spectra of human kidney perfusate showed that after ischemia, glucose was increased and glutathione decreased. Other metabolites, not initially present in the solution, appeared at the end of the perfusion as a result of metabolic activities. Among them, metabolites related to fatty acid metabolism (3-hydroxybutyrate), anaerobic glycolysis (lactate) and the tricarboxylic acid (TCA) cycle (citrate, glutamate) significantly increased over time. Moreover, different 
metabolite patterns were observed in samples in which DGF occurred, featuring lower gluconate, glucose and inosine values, and higher leucine values [95].

A metabolomic study of urinary output in an animal model of IRI showed that biochemical markers of renal damage (trimethylamine-N-oxide, TMAO) and mitochondrial dysfunction (citrate, lactate, acetate) were increased. In this context, TMAO, lactate and acetate excretion were related to graft injury and a lower concentration of urinary citrate was correlated with DGF [94]. Other studies have investigated the alteration of the metabolic status during the different phases of the I/R injury. Alterations in energy pathways, oxidative stress and transport function reflect the metabolic status of the kidney. During the ischemia phase, higher concentrations of serum glutamate, serine, isovalerylglycine, proline, aminobutyrate and choline were observed. After reperfusion, instead, high urinary concentrations of citrate, pyruvate and 3-hydroxybutyrate reflected the impaired TCA cycle activity. Consequently, the impairment of oxidative phosphorylation in turn alters ATPdependent tubular transport, which is reflected in a high urinary content of amino acids (3-aminoisobutyrate, betaine, carnosine and N-phenylacetylglycine). Moreover, the impaired tubular secretion of organic anions is highlighted by a markedly decreased urinary output of hippurate after reperfusion, lasting up to $11 \mathrm{~h} \mathrm{[96].}$

Metabolic impairment after IRI is harder to investigate in humans, since different confounding issues arise; for example, the intake of cyclosporin A (CsA) alters the kidney metabolism in a very similar manner to I/R. Healthy volunteers, in fact, showed higher levels in urine and blood of many metabolites related to oxidative stress such as glutathione, or involving the energy metabolism such as glucose, lactate and citrate [95]. Calcineurin inhibitors (CNI) have the same effects as CsA on the kidney metabolism, limiting the possibility of conducting metabolic studies in the earlier phases of transplantation, when these kinds of drugs are not yet administered. Domanski et al. conducted a metabolomics analysis of blood samples drawn from the renal vein 5 min after reperfusion. A significant increase of hypoxanthine and xanthine was found, reflecting the enhanced degradation of ATP, which promotes reactive oxygen species generation and energetic impairment [97].

Recently, to investigate molecular and metabolic pathways involved in IRI, the transcriptome of specimens during ischemia and reperfusion was studied. Zhang et al. performed gene set enrichment and genome analysis to determine which pathways are significantly expressed upon IRI. They showed that the NOD-like receptor signaling pathway and its two downstream signaling pathways, mitogen-activated protein kinase (MAPK) and NF-kB, are the major pathways found to be significantly enriched. This study revealed the pivotal role of the NOD-like receptor signaling pathway and the relationship between its effectors and the infiltration of specific immune cell types during IRI. This interplay involves hematopoietic stem cells, M2 macrophages, monocytes, Treg cells, conventional dendritic cells and pro B-cells, whose infiltration is strongly correlated with the expression of the MAPK and NF-kB signaling pathways [98].

\section{Potential Prevention and Therapeutic Strategies}

Many drugs have been investigated for the purposes of preventing DGF. Eculizumab is an anti-human C5 micro antibody that has shown potential in the prevention and/or treatment in antibody-mediated rejection (AMR) and a good safety profile in several phase 2/3 trials (NCT01567085, NCT01106027, NCT01399593). In preventing DGF, the safety profile of Eculizumab was good, but pre-treatment had no effect on the incidence of DGF [99-102]. Another anti-C5 antibody, Tesidolumab, has currently entered a phase 1 study. Safety studies show a potentially good safety profile in interaction with other drugs, but no data on efficacy have been published yet [103].

C1 esterase inhibitors (C1-INH) should not be considered complement-specific inhibitors, since they act as protease inhibitors and may play a role beyond the classical complement pathway and even beyond the entire complement system. C1INH Berinert ${ }^{\circledR}$ (CSL Behring, King of Prussia, PA, USA) has been evaluated in a phase 1/2, double-blind, placebo-controlled study. Its safety and efficacy profile for the prevention of DGF in re- 
cipients of deceased donor kidneys was investigated. Even though the primary outcome measure (DGF) was not met, treatment with Berinert ${ }^{\circledR}$ was associated with significant fewer dialysis sessions 2-4 weeks post-transplant. Furthermore, comparing the placebo group with the treated subjects, a better renal function was shown at 1 year, with no adverse effects and a good safety profile [103].

RNA interference (RNAi) through small interfering RNA (siRNA) and short hairpin RNA (shRNA) are potential weapons that may be used to silence damage-related genes before reperfusion. To prevent IRI, the importance and the utility of RNAi have been demonstrated in several animal models of solid organ transplantation. RNAi has been tested in kidney transplantation to target C3, Fas, Caspase 3 and 8, Rel B and CD40, yielding good results. Their effects showed a reduced apoptosis and a better appearance at histology, related to a better renal function, which seemed well preserved. Further studies are needed to explore this preventive option and to better define its safety profile and effectiveness in humans $[104,105]$.

Finally, additional strategies in organ preservation techniques and reperfusion have been studied to achieve better clinical outcomes. The addition of metabolic intermediates to preservation solutions was the first attempt to improve their efficacy, which led to the most used preservation solutions to date (Collins, Univerity of Wisconsin, Celsior, Histidin-Tryptophan-Ketoglutarat, Hypertonic Citrate-Adenine). The postulated benefits of these supplementations include the reduction of calcium overload, increased tissue ATP concentration, sodium re-absorption and a lower cellular damage. Recently, the addition of gases has been studied in animal models. Argon-saturated celsior solution (Ar-Celsior) was tested in a swine kidney transplantation model, resulting in better graft recovery and survival associated with reduced tissue damage. Moreover, the addition of carbon monoxide (CO) to the University of Wisconsin (UW) solution was tested. In a porcine and rat model, UW supplemented with $\mathrm{CO}$ showed a protective role against IRI, considering the role of $\mathrm{CO}$ in lowering pro-inflammatory cytokines and lipid peroxidation [106-109].

Besides the addition of amino acids, protein and peptide supplementation to preservation solutions has been studied with a good efficacy in animal models $[110,111]$. Moreover, preservation solutions supplemented with pathway modulators of IRI, such as oligonucleotides, inhibitors and siRNA, have been recently investigated. The addition of caspase 3 siRNA in preservation solution in a swine model showed reduced levels of cell apoptosis and better acid-base homeostasis. Similarly, the addition of matrix metalloproteinase (MMP)-2 siRNA showed a protective role against IRI, reducing tissue fibrosis in a rat transplantation model [112,113]. A deeper knowledge of the mechanism underlying IRI would suggest further strategies to improve the preservation solutions currently used in clinical practice.

\section{Conclusions}

Research on kidney transplant recipients in the past decades has been focused on immunosuppression and post-transplant patient management. Nevertheless, the complex process of implantation and reperfusion at the time of transplantation, involving the entire IRI pathophysiological mechanism, plays a pivotal role in the outcome of kidney graft recipients. As discussed above, the cornerstone of the IRI cascade is the uncontrolled ROS formation during reperfusion and the mitochondrial dysfunction, which cause the mPTP to open and the release of DAMPs in the intra- and extracellular space. Several injury pathways are activated, including apoptosis and necrosis, endothelial dysfunction, loss of the specific phenotype of endothelial cells and activation of the immune system. The activation of the innate, and subsequently, the adaptive immune system leads to further injury of the graft, associated with a higher immunogenicity of the kidney and promoting T-cell- and antibody-mediated rejection. Novel insights have been gained into complement activation upon IRI, showing its importance in the crosstalk with immune cells and its role in renal fibrosis associated with chronic graft dysfunction and DGF. Currently, several pathways are being investigated as potential targets of novel pharmacological agents, 
although most of those are still in the preclinical phase and further studies are needed. Modulation of the complement could be a very attractive strategy, since it seems to play an effective, central role in IRI-related dysfunction. Moreover, potential targets could be identified in the earlier phases of IRI, such as mitochondrial dysfunction, considering its central role in the initiation of IRI, and new interesting options such as RNA interference could be potential future strategies. However, in view of the complexity of these events, our knowledge is still too limited to adequately counteract IRI, and more studies are needed to better elucidate the pathological events occurring in this multifactorial process. We could predict that a multiple treatment approach, targeting agents at various times of the whole transplantation process (organ retrieval, preservation and transplantation itself) will most likely be the best approach to reduce IRI, improving graft survival and patients' quality of life.

Author Contributions: Conceptualization, G.L.; methodology, D.L. and G.L.; formal analysis, D.L.; data curation, all authors; writing - original draft preparation, D.L. and G.L.; writing-review and editing, all authors; supervision, G.L. All authors have read and agreed to the published version of the manuscript.

Funding: This research received no external funding.

Conflicts of Interest: The authors declare no conflict of interest.

\section{References}

1. GBD Chronic Kidney Disease Collaboration. Global, regional, and national burden of chronic kidney disease, 1990-2017: A systematic analysis for the Global Burden of Disease Study 2017. Lancet 2020, 395, 709-733. [CrossRef]

2. Global Observatory of Donation and Transplantation. Available online: http://www.transplant-observatory.org/ (accessed on 15 March 2021).

3. Losappio, V.; Stallone, G.; Infante, B.; Schena, A.; Rossini, M.; Maiorano, A.; Fiorentino, M.; Ditonno, P.; Lucarelli, G.; Battaglia, M.; et al. A single-center cohort study to define the role of pretransplant biopsy score in the long-term outcome of kidney transplantation. Transplantation 2014, 97, 934-939. [CrossRef]

4. Vavallo, A.; Lucarelli, G.; Spilotros, M.; Bettocchi, C.; Palazzo, S.; Selvaggi, F.P.; Battaglia, M.; Ditonno, P. Impact of donor-recipient gender on kidney graft and patient survival: Short- and long-term outcomes. World J. Urol. 2014, 32, 709-714. [CrossRef] [PubMed]

5. Hill, C.J.; Courtney, A.E.; Cardwell, C.R.; Maxwell, A.P.; Lucarelli, G.; Veroux, M.; Furriel, F.; Cannon, R.M.; Hoogeveen, E.K.; Doshi, M.; et al. Recipient obesity and outcomes after kidney transplantation: A systematic review and meta-analysis. Nephrol. Dial. Transpl. 2015, 30, 1403-1411. [CrossRef] [PubMed]

6. Impedovo, S.V.; De Lorenzis, E.; Volpe, A.; Gesualdo, L.; Grandaliano, G.; Palazzo, S.; Lucarelli, G.; Bettocchi, C.; Terrone, C.; Stratta, P.; et al. Middle and long-term outcomes of dual kidney transplant: A multicenter experience. Transpl. Proc. 2013, 45, 1237-1241. [CrossRef] [PubMed]

7. Lucarelli, G.; Bettocchi, C.; Battaglia, M.; Impedovo, S.V.; Vavallo, A.; Grandaliano, G.; Castellano, G.; Schena, F.P.; Selvaggi, F.P.; Ditonno, P. Extended criteria donor kidney transplantation: Comparative outcome analysis between single versus double kidney transplantation at 5 years. Transpl. Proc. 2010, 42, 1104-1107. [CrossRef]

8. Ditonno, P.; Lucarelli, G.; Impedovo, S.V.; Spilotros, M.; Grandaliano, G.; Selvaggi, F.P.; Bettocchi, C.; Battaglia, M. Obesity in kidney transplantation affects renal function but not graft and patient survival. Transpl. Proc. 2011, 43, 367-372. [CrossRef]

9. Querard, A.H.; Foucher, Y.; Combescure, C.; Dantan, E.; Larmet, D.; Lorent, M.; Pouteau, L.; Giral, M.; Gillaizeau, F. Comparison of survival outcomes between Expanded Criteria Donor and Standard Criteria Donor kidney transplant recipients: A systematic review and meta-analysis. Transpl. Int. 2016, 29, 403-415. [CrossRef] [PubMed]

10. Heylen, L.; Pirenne, J.; Samuel, U.; Tieken, I.; Naesens, M.; Sprangers, B.; Jochmans, I. The Impact of Anastomosis Time During Kidney Transplantation on Graft Loss: A Eurotransplant Cohort Study. Am. J. Transpl. 2017, 17, 724-732. [CrossRef]

11. Summers, D.M.; Watson, C.J.; Pettigrew, G.J.; Johnson, R.J.; Collett, D.; Neuberger, J.M.; Bradley, J.A. Kidney donation after circulatory death (DCD): State of the art. Kidney Int. 2015, 88, 241-249. [CrossRef]

12. Breda, A.; Lucarelli, G.; Rodriguez-Faba, O.; Guirado, L.; Facundo, C.; Bettocchi, C.; Gesualdo, L.; Castellano, G.; Grandaliano, G.; Battaglia, M.; et al. Clinical and pathological outcomes of renal cell carcinoma (RCC) in native kidneys of patients with end-stage renal disease: A long-term comparative retrospective study with RCC diagnosed in the general population. World J. Urol. 2015, 33, 1-7, Correction in 2015, 33, 9. [CrossRef] [PubMed]

13. Lucarelli, G.; Ditonno, P. Editorial comment from Dr Lucarelli and Dr Ditonno to Impact of graft nephrectomy on outcomes of second kidney transplantation. Int. J. Urol. 2014, 21, 802-803. [CrossRef] [PubMed] 
14. Lucarelli, G.; Vavallo, A.; Bettocchi, C.; Losappio, V.; Gesualdo, L.; Grandaliano, G.; Selvaggi, F.P.; Battaglia, M.; Ditonno, P. Impact of transplant nephrectomy on retransplantation: A single-center retrospective study. World J. Urol. 2013, 31, 959-963. [CrossRef]

15. Vavallo, A.; Lucarelli, G.; Bettocchi, C.; Tedeschi, M.; Palazzo, S.; Losappio, V.; Gesualdo, L.; Grandaliano, G.; Selvaggi, F.P.; Battaglia, M.; et al. Allograft nephrectomy: What is the best surgical technique? Transpl. Proc. 2012, 44, 1922-1925. [CrossRef] [PubMed]

16. Ponticelli, C. Ischemia-reperfusion injury: A major protagonist in kidney transplantation. Nephrol. Dial. Transpl. 2014, 29, 1134-1140. [CrossRef]

17. Cooper, J.E.; Wiseman, A.C. Acute kidney injury in kidney transplantation. Curr. Opin. Nephrol. Hypertens. 2013, 22, 698-703. [CrossRef]

18. Salvadori, M.; Rosso, G.; Bertoni, E. Update on ischemia-reperfusion injury in kidney transplantation: Pathogenesis and treatment. World J. Transpl. 2015, 5, 52-67. [CrossRef] [PubMed]

19. Edelstein, C.L.; Ling, H.; Schrier, R.W. The nature of cell injury. Kidney Int. 1997, 51, 1341-1351. [CrossRef] [PubMed]

20. Becker, L.B. New concepts in reactive oxygen species and cardiovascular reperfusion physiology. Cardiovasc. Res. 2004, 61, 461-470. [CrossRef]

21. Alkaitis, M.S.; Crabtree, M.J. Recoupling the cardiac nitric oxide synthases: Tetrahydrobiopterin synthesis and recycling. Curr. Heart Fail. Rep. 2012, 9, 200-210. [CrossRef]

22. Li, C.; Jackson, R.M. Reactive species mechanisms of cellular hypoxia-reoxygenation injury. Am. J. Physiol. Cell Physiol. 2002, 282, C227-C241. [CrossRef]

23. Simone, S.; Rascio, F.; Castellano, G.; Divella, C.; Chieti, A.; Ditonno, P.; Battaglia, M.; Crovace, A.; Stafferi, F.; Oortwijn, B.; et al. Complement-dependent NADPH oxidase enzyme activation in renal ischemia/reperfusion injury. Free Radic. Biol. Med. 2014, 74, 263-273. [CrossRef]

24. Martin, J.L.; Gruszczyk, A.V.; Beach, T.E.; Murphy, M.P.; Saeb-Parsy, K. Mitochondrial mechanisms and therapeutics in ischaemia reperfusion injury. Pediatr. Nephrol. 2019, 34, 1167-1174. [CrossRef] [PubMed]

25. Weinlich, R.; Oberst, A.; Beere, H.M.; Green, D.R. Necroptosis in development, inflammation and disease. Nat. Rev. Mol. Cell Biol. 2017, 18, 127-136. [CrossRef] [PubMed]

26. Zhang, Q.; Raoof, M.; Chen, Y.; Sumi, Y.; Sursal, T.; Junger, W.; Brohi, K.; Itagaki, K.; Hauser, C.J. Circulating mitochondrial DAMPs cause inflammatory responses to injury. Nature 2010, 464, 104-107. [CrossRef]

27. Faller, D.V. Endothelial cell responses to hypoxic stress. Clin. Exp. Pharmacol. Physiol. 1999, 26, 74-84. [CrossRef]

28. Kwon, O.; Hong, S.M.; Ramesh, G. Diminished NO generation by injured endothelium and loss of macula densa nNOS may contribute to sustained acute kidney injury after ischemia-reperfusion. Am. J. Physiol. Renal. Physiol. 2009, 296, 25-33. [CrossRef] [PubMed]

29. Bonventre, J.V.; Yang, L. Cellular pathophysiology of ischemic acute kidney injury. J. Clin. Investig. 2011, 121, 4210-4221. [CrossRef]

30. Legrand, M.; Mik, E.G.; Johannes, T.; Payen, D.; Ince, C. Renal hypoxia and dysoxia after reperfusion of the ischemic kidney. Mol. Med. 2008, 14, 502-516. [CrossRef]

31. Kwon, O.; Hong, S.M.; Sutton, T.A.; Temm, C.J. Preservation of peritubular capillary endothelial integrity and increasing pericytes may be critical to recovery from postischemic acute kidney injury. Am. J. Physiol. Renal. Physiol. 2008, 295, F351-F359. [CrossRef]

32. Curci, C.; Castellano, G.; Stasi, A.; Divella, C.; Loverre, A.; Gigante, M.; Simone, S.; Cariello, M.; Montinaro, V.; Lucarelli, G.; et al. Endothelial-to-mesenchymal transition and renal fibrosis in ischaemia/reperfusion injury are mediated by complement anaphylatoxins and Akt pathway. Nephrol. Dial. Transpl. 2014, 29, 799-808. [CrossRef]

33. Eltzschig, H.K.; Collard, C.D. Vascular ischemia and reperfusion injury. Br. Med. Bull. 2004, 70, 71-86. [CrossRef] [PubMed]

34. Carden, D.L.; Granger, D.N. Pathophysiology of ischemia reperfusion injury. J. Pathol. 2000, 190, 255-266. [CrossRef]

35. O'Neill, L.A.; Bowie, A.G. The family of five: TIR-domain-containing adaptors in Toll-like receptor signalling. Nat. Rev. Immunol. 2007, 7, 353-364. [CrossRef]

36. Delneste, Y.; Beauvillain, C.; Jeannin, P. Innate immunity: Structure and function of TLRs. Med. Sci. 2007, 23, 67-73.

37. Kawasaki, T.; Kawai, T. Toll-Like receptor signaling pathways. Front. Immunol. 2014, 5, 461. [CrossRef]

38. Rusai, K.; Sollinger, D.; Baumann, M.; Wagner, B.; Strobl, M.; Schmaderer, C.; Roos, M.; Kirschning, C.; Heemann, U.; Lutz, J. Toll-like receptors 2 and 4 in renal ischemia/reperfusion injury. Pediatr. Nephrol. 2010, 25, 853-860. [CrossRef]

39. Kruger, B.; Krick, S.; Dhillon, N.; Lerner, S.M.; Ames, S.; Bromberg, J.S.; Lin, M.; Walsh, L.; Vella, J.; Fischereder, M.; et al. Donor Toll-like receptor 4 contributes to ischemia and reperfusion injury following human kidney transplantation. Proc. Natl. Acad. Sci. USA 2009, 106, 3390-3395. [CrossRef]

40. Wu, H.; Chen, G.; Wyburn, K.R.; Yin, J.; Bertolino, P.; Eris, J.M.; Alexander, S.I.; Sharland, A.F.; Chadban, S.J. TLR4 activation mediates kidney ischemia/reperfusion injury. J. Clin. Investig. 2007, 117, 2847-2859. [CrossRef]

41. Chen, J.; John, R.; Richardson, J.A.; Shelton, J.M.; Zhou, X.J.; Wang, Y.; Wu, Q.Q.; Hartono, J.R.; Winterberg, P.D.; Lu, C.Y. Toll-like receptor 4 regulates early endothelial activation during ischemic acute kidney injury. Kidney Int. 2011, 79, 288-299. [CrossRef] [PubMed]

42. Jang, H.R.; Rabb, H. The innate immune response in ischemic acute kidney injury. Clin. Immunol. 2009, 130, 41-50. [CrossRef] [PubMed] 
43. Jo, S.K.; Sung, S.A.; Cho, W.Y.; Go, K.J.; Kim, H.K. Macrophages contribute to the initiation of ischemic acute renal failure in rats. Nephrol. Dial. Transpl. 2006, 21, 1231-1239. [CrossRef] [PubMed]

44. Liu, Y. Cellular and molecular mechanisms of renal fibrosis. Nat. Rev. Nephrol. 2011, 7, 684-696. [CrossRef]

45. Leemans, J.C.; Butter, L.M.; Pulskens, W.P.; Teske, G.J.D.; Claessen, N.; van der Poll, T.; Florquin, S. The role of Toll-like receptor 2 in inflammation and fibrosis during progressive renal injury. PLoS ONE 2009, 4, e5704. [CrossRef]

46. Leemans, J.C.; Stokman, G.; Claessen, N.; Rouschop, K.M.; Teske, G.J.D.; Kirschning, C.J.; Akira, S.; van der Poll, T.; Weening, J.J.; Florquin, S. Renal-associated TLR2 mediates ischemia/reperfusion injury in the kidney. J. Clin. Investig. 2005, 115, $2894-2903$. [CrossRef]

47. Reilly, M.; Miller, R.M.; Thomson, M.H.; Patris, V.; Ryle, P.; McLoughlin, L.; Mutch, P.; Gilboy, P.; Miller, C.; Broekema, M.; et al. Randomized, double-blind, placebo-controlled, dose-escalating phase I, healthy subjects study of intravenous OPN-305, a humanized Anti-TLR2 antibody. Clin. Pharmacol. Ther. 2013, 94, 593-600. [CrossRef]

48. Snelgrove, S.L.; Lo, C.; Hall, P.; Lo, C.Y.; Alikhan, M.A.; Coates, P.T.; Holdsworth, S.R.; Hickey, M.J.; Kitching, A.R. Activated Renal Dendritic Cells Cross Present Intrarenal Antigens After Ischemia-Reperfusion Injury. Transplantation 2017, 101, 1013-1024. [CrossRef] [PubMed]

49. Damman, J.; Daha, M.R.; van Son, W.J.; Leuvenink, H.G.; Ploeg, R.J.; Seelen, M.A. Crosstalk between complement and Toll-like receptor activation in relation to donor brain death and renal ischemia-reperfusion injury. Am. J. Transpl. 2011, 11, 660-669. [CrossRef] [PubMed]

50. Batal, I.; De Serres, S.A.; Safa, K.; Bijol, V.; Ueno, T.; Onozato, M.L.; Iafrate, A.J.; Herter, J.M.; Lichtman, A.H.; Mayadas, T.N.; et al. Dendritic Cells in Kidney Transplant Biopsy Samples Are Associated with T Cell Infiltration and Poor Allograft Survival. J. Am. Soc. Nephrol. 2015, 26, 3102-3113. [CrossRef]

51. Bajwa, A.; Huang, L.; Ye, H.; Dondeti, K.; Song, S.; Rosin, D.L.; Lynch, K.R.; Lobo, P.I.; Li, L.; Okusa, M.D. Dendritic cell sphingosine 1-phosphate receptor-3 regulates Th1-Th2 polarity in kidney ischemia-reperfusion injury. J. Immunol. 2012, 189, 2584-2596. [CrossRef]

52. Benichou, G.; Thomson, A.W. Direct versus indirect allorecognition pathways: On the right track. Am. J. Transpl. 2009, 9, 655-656. [CrossRef]

53. Ysebaert, D.K.; De Greef, K.E.; De Beuf, A.; Van Rompay, A.R.; Vercauteren, S.; Persy, V.P.; De Broe, M.E. T-cells as mediators in renal ischemia/reperfusion injury. Kidney Int. 2004, 66, 491-496. [CrossRef] [PubMed]

54. De Perrot, M.; Young, K.; Imai, Y.; Liu, M.; Waddell, T.K.; Fischer, S.; Zhang, L.; Keshavjee, S. Recipient T cells mediate reperfusion injury after lung transplantation in the rat. J. Immunol. 2003, 171, 4995-5002. [CrossRef]

55. Fiorina, P.; Ansari, M.J.; Jurewicz, M.; Barry, M.; Ricchiuti, V.; Smith, R.N.; Shea, S.; Means, T.K.; Auchincloss, H., Jr.; Luster, A.D.; et al. Role of CXC chemokine receptor 3 pathway in renal ischemic injury. J. Am. Soc. Nephrol. 2006, 17, 716-723. [CrossRef] [PubMed]

56. Rabb, H. The $\mathrm{T}$ cell as a bridge between innate and adaptive immune systems: Implications for the kidney. Kidney Int. 2002, 61, 1935-1946. [CrossRef]

57. Lee, J.W.; Bae, E.; Kwon, S.H.; Yu, M.Y.; Cha, R.H.; Lee, H.; Kim, D.K.; Lee, J.P.; Ye, S.K.; Yoo, J.Y.; et al. Transcriptional modulation of the T helper 17/interleukin 17 axis ameliorates renal ischemia-reperfusion injury. Nephrol. Dial. Transpl. 2019, 34, 1481-1498. [CrossRef]

58. Loverre, A.; Divella, C.; Castellano, G.; Tataranni, T.; Zaza, G.; Rossini, M.; Ditonno, P.; Battaglia, M.; Palazzo, S.; Gigante, M.; et al. T helper 1, 2 and 17 cell subsets in renal transplant patients with delayed graft function. Transpl. Int. 2011, 24, 233-242. [CrossRef]

59. Afzali, B.; Lombardi, G.; Lechler, R.I.; Lord, G.M. The role of T helper 17 (Th17) and regulatory T cells (Treg) in human organ transplantation and autoimmune disease. Clin. Exp. Immunol. 2007, 148, 32-46. [CrossRef]

60. Loong, C.C.; Hsieh, H.G.; Lui, W.Y.; Chen, A.; Lin, C.Y. Evidence for the early involvement of interleukin 17 in human and experimental renal allograft rejection. J. Pathol. 2002, 197, 322-332. [CrossRef]

61. Tang, J.L.; Subbotin, V.M.; Antonysamy, M.A.; Troutt, A.B.; Rao, A.S.; Thomson, A.W. Interleukin-17 antagonism inhibits acute but not chronic vascular rejection. Transplantation 2001, 72, 348-350. [CrossRef]

62. Ko, G.J.; Linfert, D.; Jang, H.R.; Higbee, E.; Watkins, T.; Cheadle, C.; Liu, M.; Racusen, L.; Grigoryev, D.N.; Rabb, H. Transcriptional analysis of infiltrating T cells in kidney ischemia-reperfusion injury reveals a pathophysiological role for CCR5. Am. J. Physiol. Renal. Physiol. 2012, 302, F762-F773. [CrossRef]

63. Waldmann, H.; Hilbrands, R.; Howie, D.; Cobbold, S. Harnessing FOXP3p regulatory T cells for transplantation tolerance. J. Clin. Investig. 2014, 124, 1439-1445. [CrossRef]

64. Wood, K.J.; Sakaguchi, S. Regulatory T cells in transplantation tolerance. Nat. Rev. Rheumatol. 2003, 3, 199-210. [CrossRef]

65. Ferrer, I.R.; Hester, J.; Bushell, A.; Wood, K.J. Induction of transplantation tolerance through regulatory cells: From mice to men. Immunol. Rev. 2014, 258, 102-116. [CrossRef]

66. Kinsey, G.; Sharma, R.; Huang, L.; Li, L.; Vergis, A.L.; Ye, H.; Ju, S.T.; Okusa, M.D. Regulatory T Cells Suppress Innate Immunity in Kidney Ischemia-Reperfusion Injury. J. Am. Soc. Nephrol. 2009, 20, 1744-1753. [CrossRef] [PubMed]

67. Hu, M.; Wang, Y.M.; Wang, Y.; Zhang, G.Y.; Zheng, G.; Yi, S.; O'Connell, P.J.; Harris, D.C.; Alexander, S.I. Regulatory T cells in kidney disease and transplantation. Kidney Int. 2016, 90, 502-514. [CrossRef] [PubMed] 
68. Braza, F.; Dugast, E.; Panov, I.; Paul, C.; Vogt, K.; Pallier, A.; Chesneau, M.; Baron, D.; Guerif, P.; Lei, H.; et al. Central role of CD45RA- Foxp3hi memory regulatory T cells in clinical kidney transplantation tolerance. J. Am. Soc. Nephrol. 2015, 26, $1795-1805$. [CrossRef] [PubMed]

69. Duhen, T.; Duhen, R.; Lanzavecchia, A.; Sallusto, F.; Campbell, D.J. Functionally distinct subsets of human FOXP3 Treg cells that phenotypically mirror effector Th cells. Blood 2012, 119, 4430-4440. [CrossRef]

70. Kawai, M.; Kitade, H.; Mathieu, C.; Waer, M.; Pirenne, J. Inhibitory and stimulatory effects of cyclosporine A on the development of regulatory T cells in vivo. Transplantation 2005, 79, 1073-1077. [CrossRef] [PubMed]

71. Nauser, C.L.; Farrar, C.A.; Sacks, S.H. Complement Recognition Pathways in Renal Transplantation. J. Am. Soc. Nephrol. 2017, 28, 2571-2578. [CrossRef]

72. Farrar, C.A.; Tran, D.; Li, K.; Wu, W.; Peng, Q.; Schwaeble, W.; Zhou, W.; Sacks, S.H. Collectin-11 detects stress-induced l-fucose pattern to trigger renal epithelial injury. J. Clin. Investig. 2016, 126, 1911-1925. [CrossRef]

73. Asgari, E.; Farrar, C.A.; Lynch, N.; Ali, Y.M.; Roscher, S.; Stover, C.; Zhou, W.; Schwaeble, W.J.; Sacks, S.H. Mannan-binding lectin-associated serine protease 2 is critical for the development of renal ischemia reperfusion injury and mediates tissue injury in the absence of complement C4. FASEB J. 2014, 28, 3996-4003. [CrossRef]

74. Wallis, R. Interactions between mannose binding lectin and MASPs during complement activation by the lectin pathway. Immunobiology 2007, 212, 289-299. [CrossRef] [PubMed]

75. Janewit, D.; Surovtseva, Y.V.; Qin, L.; Li, G.; Liu, R.; Clark, P.; Manes, T.D.; Wang, C.; Kashgarian, M.; Kirkiles-Smith, N.C.; et al. Complement membrane attack complexes activate noncanonical NF-kB by forming an $\mathrm{Akt}^{+} \mathrm{NIK}^{+}$signalosome on Rab5 ${ }^{+}$ endosomes. Proc. Natl. Acad. Sci. USA 2015, 112, 9686-9969. [CrossRef] [PubMed]

76. Yamanaka, K.; Kakuta, Y.; Miyagawa, S.; Nakazawa, S.; Kato, T.; Abe, T.; Imamura, R.; Okumi, M.; Maeda, A.; Okuyama, H.; et al. Depression of complement regulatory factors in rat and human renal grafts is associated with the progress of acute T-cell mediated rejection. PLoS ONE 2016, 11, e0148881. [CrossRef] [PubMed]

77. Castellano, G.; Franzin, R.; Stasi, A.; Divella, C.; Sallustio, F.; Pontrelli, P.; Lucarelli, G.; Battaglia, M.; Staffieri, F.; Crovace, A.; et al. Complement Activation During Ischemia/ Reperfusion Injury Induces Pericyte-to-Myofibroblast Transdifferentiation Regulating Peritubular Capillary Lumen Reduction Through pERK Signaling. Front. Immunol. 2018, 9, 1002. [CrossRef] [PubMed]

78. Divella, C.; Stasi, A.; Franzin, R.; Rossini, M.; Pontrelli, P.; Sallustio, F.; Netti, G.S.; Ranieri, E.; Lacitignola, L.; Staffieri, F.; et al. Pentraxin-3-mediated complement activation in a swine model of renal ischemia/reperfusion injury. Aging 2021, 13, 10920-10933. [CrossRef] [PubMed]

79. Castellano, G.; Franzin, R.; Sallustio, F.; Stasi, A.; Banelli, B.; Romani, M.; De Palma, G.; Lucarelli, G.; Divella, C.; Battaglia, M.; et al. Complement component C5a induces aberrant epigenetic modifications in renal tubular epithelial cells accelerating senescence by Wnt4/ ßcatenin signaling after ischemia/reperfusion injury. Aging 2019, 11, 4382-4406. [CrossRef]

80. Castellano, G.; Intini, A.; Stasi, A.; Divella, C.; Gigante, M.; Pontrelli, P.; Franzin, R.; Accetturo, M.; Zito, A.; Fiorentino, M.; et al. Complement Modulation of Anti-Aging Factor Klotho in Ischemia/Reperfusion Injury and Delayed Graft Function. Am. J. Transpl. 2016, 16, 325-333. [CrossRef]

81. Lucarelli, G.; Galleggiante, V.; Rutigliano, M.; Sanguedolce, F.; Cagiano, S.; Bufo, P.; Lastilla, G.; Maiorano, E.; Ribatti, D.; Giglio, A.; et al. Metabolomic profile of glycolysis and the pentose phosphate pathway identifies the central role of glucose-6-phosphate dehydrogenase in clear cell-renal cell carcinoma. Oncotarget 2015, 6, 13371-13386. [CrossRef] [PubMed]

82. Lucarelli, G.; Rutigliano, M.; Galleggiante, V.; Giglio, A.; Palazzo, S.; Ferro, M.; Simone, C.; Bettocchi, C.; Battaglia, M.; Ditonno, P. Metabolomic profiling for the identification of novel diagnostic markers in prostate cancer. Expert Rev. Mol. Diagn. 2015, 15, 1211-1224. [CrossRef]

83. Lucarelli, G.; Rutigliano, M.; Sanguedolce, F.; Galleggiante, V.; Giglio, A.; Cagiano, S.; Bufo, P.; Maiorano, E.; Ribatti, D.; Ranieri, E.; et al. Increased Expression of the Autocrine Motility Factor is Associated with Poor Prognosis in Patients with Clear Cell-Renal Cell Carcinoma. Medicine 2015, 94, e2117. [CrossRef]

84. Ragone, R.; Sallustio, F.; Piccinonna, S.; Rutigliano, M.; Vanessa, G.; Palazzo, S.; Lucarelli, G.; Ditonno, P.; Battaglia, M.; Fanizzi, F.P.; et al. Renal Cell Carcinoma: A Study through NMR-Based Metabolomics Combined with Transcriptomics. Diseases $2016,4,7$. [CrossRef]

85. Lucarelli, G.; Rutigliano, M.; Ferro, M.; Giglio, A.; Intini, A.; Triggiano, F.; Palazzo, S.; Gigante, M.; Castellano, G.; Ranieri, E.; et al. Activation of the kynurenine pathway predicts poor outcome in patients with clear cell renal cell carcinoma. Urol. Oncol. 2017, 35, 461.e15-461.e27. [CrossRef] [PubMed]

86. Bianchi, C.; Meregalli, C.; Bombelli, S.; Di Stefano, V.; Salerno, F.; Torsello, B.; De Marco, S.; Bovo, G.; Cifola, I.; Mangano, E.; et al. The glucose and lipid metabolism reprogramming is grade-dependent in clear cell renal cell carcinoma primary cultures and is targetable to modulate cell viability and proliferation. Oncotarget 2017, 8, 113502-113515. [CrossRef]

87. Lucarelli, G.; Loizzo, D.; Franzin, R.; Battaglia, S.; Ferro, M.; Cantiello, F.; Castellano, G.; Bettocchi, C.; Ditonno, P.; Battaglia, M. Metabolomic insights into pathophysiological mechanisms and biomarker discovery in clear cell renal cell carcinoma. Expert Rev. Mol. Diagn. 2019, 19, 397-407. [CrossRef]

88. Lucarelli, G.; Loizzo, D.; Ferro, M.; Rutigliano, M.; Vartolomei, M.D.; Cantiello, F.; Buonerba, C.; Di Lorenzo, G.; Terracciano, D.; De Cobelli, O.; et al. Metabolomic profiling for the identification of novel diagnostic markers and therapeutic targets in prostate cancer: An update. Expert Rev. Mol. Diagn. 2019, 19, 377-387. [CrossRef] 
89. Lucarelli, G.; Rutigliano, M.; Sallustio, F.; Ribatti, D.; Giglio, A.; Lepore Signorile, M.; Grossi, V.; Sanese, P.; Napoli, A.; Maiorano, E.; et al. Integrated multi-omics characterization reveals a distinctive metabolic signature and the role of NDUFA4L2 in promoting angiogenesis, chemoresistance, and mitochondrial dysfunction in clear cell renal cell carcinoma. Aging 2018, 10, 3957-3985. [CrossRef]

90. Bombelli, S.; Torsello, B.; De Marco, S.; Lucarelli, G.; Cifola, I.; Grasselli, C.; Strada, G.; Bovo, G.; Perego, R.A.; Bianchi, C. 36-kDa Annexin A3 Isoform Negatively Modulates Lipid Storage in Clear Cell Renal Cell Carcinoma Cells. Am. J. Pathol. 2020, 190, 2317-2326. [CrossRef] [PubMed]

91. Lucarelli, G.; Ferro, M.; Loizzo, D.; Bianchi, C.; Terracciano, D.; Cantiello, F.; Bell, L.N.; Battaglia, S.; Porta, C.; Gernone, A.; et al. Integration of Lipidomics and Transcriptomics Reveals Reprogramming of the Lipid Metabolism and Composition in Clear Cell Renal Cell Carcinoma. Metabolites 2020, 10, 509. [CrossRef]

92. Ferro, M.; Terracciano, D.; Buonerba, C.; Lucarelli, G.; Bottero, D.; Perdonà, S.; Autorino, R.; Serino, A.; Cantiello, F.; Damiano, R.; et al. The emerging role of obesity, diet and lipid metabolism in prostate cancer. Future Oncol. 2017, 13, 285-293. [CrossRef]

93. Lucarelli, G.; Ferro, M.; Battaglia, M. Multi-omics approach reveals the secrets of metabolism of clear cell-renal cell carcinoma. Transl. Androl. Urol. 2016, 5, 801-803. [CrossRef]

94. Barin-Le Guellec, C.; Largeau, B.; Bon, D.; Marquet, P.; Hauet, T. Ischemia/reperfusion-associated tubular cells injury in renal transplantation: Can metabolomics inform about mechanisms and help identify new therapeutic targets? Pharmacol. Res. 2018, 129, 34-43. [CrossRef] [PubMed]

95. Guy, A.J.; Nath, J.; Cobbold, M.; Ludwig, C.; Tennant, D.A.; Inston, N.G.; Ready, A.R. Metabolomic analysis of perfusate during hypothermic machine perfusion of human cadaveric kidneys. Transplantation 2015, 99, 754-759. [CrossRef] [PubMed]

96. Malagrino, P.A.; Venturini, G.; Yogi, P.S.; Dariolli, R.; Padilha, K.; Kiers, B.; Gois, T.C.; Motta-Leal-Filho, J.M.; Takimura, C.K.; Girardi, A.C.C.; et al. Metabolomic characterization of renal ischemia and reperfusion in a swine model. Life Sci. 2016, 156, 57-67. [CrossRef] [PubMed]

97. Domański, L.; Safranow, K.; Ostrowski, M.; Pawlik, A.; Olszewska, M.; Dutkiewicz, G.; Ciechanowski, K. Oxypurine and purine nucleoside concentrations in renal vein of allograft are potential markers of energy status of renal tissue. Arch. Med. Res. 2007, 38, 240-246. [CrossRef]

98. Zhang, J.; Wei, X.; Tang, Z.; Miao, B.; Luo, H.; Hu, X.; Luo, Y.; Zhou, Y.; Na, N. Elucidating the molecular pathways and immune system transcriptome during ischemia-reperfusion injury in renal transplantation. Int. Immunopharmacol. 2020, $81,106246$. [CrossRef] [PubMed]

99. Glotz, D.; Russ, G.; Rostaing, L.; Legendre, C.; Tufveson, G.; Chadban, S.; Grinyó, J.; Mamode, N.; Rigotti, P.; Couzi, L.; et al. Safety and effcacy of eculizumab for the prevention of antibody-mediated rejection after deceased-donor kidney transplantation in patients with preformed donor-specific antibodies. Am. J. Transpl. 2019, 19, 2865-2875. [CrossRef]

100. Marks, W.H.; Mamode, N.; Montgomery, R.A.; Stegall, M.D.; Ratner, L.E.; Cornell, L.D.; Rowshani, A.T.; Colvin, R.B.; Dain, B.; Boice, J.A.; et al. Safety and efficacy of eculizumab in the prevention of antibody-mediated rejection in living-donor kidney transplant recipients requiring desensitization therapy: A randomized trial. Am. J. Transpl. 2019, 19, 2876-2888. [CrossRef]

101. Schröppel, B.; Akalin, E.; Baweja, M.; Bloom, R.D.; Florman, S.; Goldstein, M.; Haydel, B.; Hricik, D.E.; Kulkarni, S.; Levine, M.; et al. Peritransplant eculizumab does not prevent delayed graft function in deceased donor kidney transplant recipients: Results of two randomized controlled pilot trials. Am. J. Transpl. 2020, 20, 564-572. [CrossRef]

102. Jordan, S.C.; Kucher, K.; Bagger, M.; Hockey, H.U.; Wagner, K.; Ammerman, N.; Vo, A. Intravenous immunoglobulin significantly reduces exposure of concomitantly administered anti-C5 monoclonal antibody tesidolumab. Am. J. Transpl. 2020, 20, 2581-2588. [CrossRef]

103. Jordan, S.C.; Choi, J.; Aubert, O.; Haas, M.; Loupy, A.; Huang, E.; Peng, A.; Kim, I.; Louie, S.; Ammerman, N.; et al. A phase I/II, double-blind, placebo-controlled study assessing safety and efficacy of C1 esterase inhibitor for prevention of delayed graft function in deceased donor kidney transplant recipients. Am. J. Transpl. 2018, 18, 2955-2964. [CrossRef] [PubMed]

104. Brüggenwirth, I.M.A.; Martins, P.N. RNA interference therapeutics in organ transplantation: The dawn of a new era. Am. J. Transpl. 2020, 20, 931-941. [CrossRef] [PubMed]

105. Cucchiari, D.; Rovira, J.; Diekmann, F. Regulated Cell Death at the Crossroad Between Ischemia-reperfusion Injury and Innate Immunity in Kidney Transplantation. Transplantation 2020, 104, 1772-1773. [CrossRef]

106. Chen, Y.; Shi, J.; Xia, T.C.; Xu, R.; He, X.; Xia, Y. Preservation Solutions for Kidney Transplantation: History, Advances and Mechanisms. Cell Transpl. 2019, 28, 1472-1489. [CrossRef]

107. Faure, A.; Bruzzese, L.; Steinberg, J.G.; Jammes, Y.; Torrents, J.; Berdah, S.V.; Garnier, E.; Legris, T.; Loundou, A.; Chalopin, M.; et al. Effectiveness of pure argon for renal transplant preservation in a preclinical pig model of heterotopic autotransplantation. $J$. Transl. Med. 2016, 14, 40. [CrossRef]

108. Ozaki, K.S.; Yoshida, J.; Ueki, S.; Pettigrew, G.L.; Ghonem, N.; Sico, R.M.; Lee, L.Y.; Shapiro, R.; Lakkis, F.G.; Pacheco-Silva, A.; et al. Carbon monoxide inhibits apoptosis during cold storage and protects kidney grafts donated after cardiac death. Transpl. Int. 2012, 25, 107-117. [CrossRef]

109. Yoshida, J.; Ozaki, K.S.; Nalesnik, M.A.; Ueki, S.; Castillo-Rama, M.; Faleo, G.; Ezzelarab, M.; Nakao, A.; Ekser, B.; Echeverri, G.J.; et al. Ex vivo application of carbon monoxide in UW solution prevents transplant-induced renal ischemia/reperfusion injury in pigs. Am. J. Transpl. 2010, 10, 763-772. [CrossRef] [PubMed] 
110. McAnulty, J.F.; Reid, T.W.; Waller, K.R.; Murphy, C.J. Successful six-day kidney preservation using trophic factor supplemented media and simple cold storage. Am. J. Transpl. 2002, 2, 712-718. [CrossRef] [PubMed]

111. Nakagawa, K.; Koo, D.D.; Davies, D.R.; Gray, D.W.; McLaren, A.J.; Welsh, K.I.; Morris, P.J.; Fuggle, S.V. Lecithinized superoxide dismutase reduces cold ischemia-induced chronic allograft dysfunction. Kidney Int. 2002, 61, 1160-1169. [CrossRef] [PubMed]

112. Yang, B.; Hosgood, S.A.; Nicholson, M.L. Naked small interfering RNA of caspase-3 in preservation solution and autologous blood perfusate protects isolated ischemic porcine kidneys. Transplantation 2011, 91, 501-507. [CrossRef] [PubMed]

113. Moser, M.A.; Arcand, S.; Lin, H.B.; Wojnarowicz, C.; Sawicka, J.; Banerjee, T.; Luo, Y.; Beck, G.R.; Luke, P.P.; Sawicki, G. Protection of the transplant kidney from preservation injury by inhibition of matrix metalloproteinases. PLoS ONE 2016, 11, e0157508. [CrossRef] [PubMed] 